\title{
Sickle cell retinopathy: diagnosis and treatment
}

\section{Retinopatia falciforme: diagnóstico e tratamento}

\author{
Maria Teresa Brizzı Chizzottı Bonanomi ${ }^{1}$, Marcelo Mendes Lavezzo ${ }^{1}$
}

\begin{abstract}
Hemoglobinopathies are a group of inherited disorders characterized by quantitative or qualitative malformations of hemoglobin $(\mathrm{Hb})$. Some of these diseases present vaso-occlusive phenomena that are responsible for high morbidity in clinical and/or ophthalmologic terms. Diagnosis of hemoglobinopathies is performed exclusively through hemoglobin electrophoresis. From the ophthalmologic perspective, the most important representative of this group of diseases is sickle cell retinopathy, which presents a wide spectrum of fundus manifestations and may even lead to irreversible vision loss if not properly diagnosed and treated. The aim of this review is to present the classification of sickle cell retinopathy and to describe current management and future perspectives for its treatment, taking into consideration the clinical management of these patients.
\end{abstract}

Keywords: Retinal diseases/diagnosis; Retinal diseases/therapy; Hemoglobin, sickle; Sickle cell trait; Hemoglobin SC disease; Vitreoretinal surgery

\section{RESUMO}

As hemoglobinopatias são um grupo de doenças hereditárias caracterizadas por mal-formações quantitativas ou qualitativas da hemoglobina ( $\mathrm{Hb}$ ). Algumas destas doenças podem apresentarfenômenosvaso-oclusivos, responsáveis poraltamorbidade do ponto de vista clínico elou oftalmológico. O diagnóstico das hemoglobinopatias é feito exclusivamente através da eletroforese de hemoglobinas. Do ponto de vista oftalmológico, a representante mais importante deste grupo de doençaséa retinopatia falciforme, que pode apresentar um amplo espectro de manifestações fundoscópicas, podendo, inclusive, levar à perda visual irreversivel se não for corretamente diagnosticada e tratada. O objetivo desta revisão é apresentar a classificação desta doença, a conduta no tratamento atual, bem como suas perspectivas futuras de tratamento, considerando-se as particularidades no manejo clínico destes pacientes.

Descritores: Doenças retinianas/diagnóstico;Doenças retinianas/terapia; Hemoglobina falciforme; Traço falciforme; Doença da hemoglobina SC; Cirurgia vitreorretiniana

\section{INTRODUCTION}

The hemoglobinopathies are a group of hereditary disorders characterized by abnormal hemoglobin $(\mathrm{Hb})$ formation. The changes in hemoglobin caused by these disorders may be quantitative or qualitative. Qualitative changes occur when the number of hemoglobin chains present is normal, but their chemical composition is changed. sickle hemoglobinopathies are part of this group.

The most common genotypes associated with hemoglobinopathies depend on the population studied. In the Brazilian population, the abnormal hemoglobins $\mathrm{S}$ and $\mathrm{C}$ are the most frequent. Using highperformance liquid chromatography analysis, the anomaly most commonly found is HbS; in one study, the most common abnormal genotype was HbAS, which occurred in $9.11 \%$ of the samples. Other genotypes represented included a genotype associated with betathalassemia in $5.50 \%$ of the samples, $\mathrm{HbAC}$ in $2.47 \%$, $\mathrm{HbSS}$ in $0.76 \%$ and $\mathrm{HbSC}$ in $0.39 \%{ }^{(1)}$. If the numbers of individuals with $\mathrm{HbS}$ and $\mathrm{HbC}$ are combined, $12.73 \%$ of the individuals analyzed display a tendency to have some type of sickle-cell abnormality.

In individuals with defective hemoglobin, the abnormal Hb undergoes a conformational change under conditions of hypoxia, acidosis, oxidative stress and infection, changing the erythrocytes into rigid sickle-shaped (sickled) cells called drepanocytes. Drepanocytes are less flexible and more prone to hemolysis than normal red blood cells, and their formation leads to various clinical manifestations of anemia and vaso-occlusive events.
The aim of this review is to describe the vitreoretinal findings related to sickle cell disease and to discuss the complications of the disease that can affect vision, as well as their treatment.

\section{EPIDEMIOLOGY AND PATHOGENESIS}

The pathophysiology of sickle cell disease is not limited to abnormalities of erythrocytes; its clinical manifestations are related to processes and complex metabolic pathways that include endothelial activation, inflammation, nitric oxide bioavailability, oxidative stress and regulation of the adhesiveness of several types of blood cells $s^{(2)}$.

The $\mathrm{Hb}$ molecule is composed of two alpha and two beta polypeptide chains. In hemoglobins S and C, an amino acid substitution occurs at position 6 of the beta chain. In HbS, glutamic acid is replaced by valine, while in $\mathrm{HbC}$ it is replaced by lysine. The diagnosis of hemoglobinopathies is performed exclusively through hemoglobin electrophoresis ${ }^{(3)}$. The sickling test cannot be used for this purpose because it is nonspecific ${ }^{(4)}$.

The sickling process is influenced by infections, dehydration and acidosis. The blood flow in terminal retinal arterioles may be decreased by the aggregation of drepanocytes, which form small plugs. Under these conditions, the available $\mathrm{Hb}$ is deoxygenated and the oxygen demand of the tissue is not supplied, resulting in tissue acidosis. This causes greater sickling, increased blood viscosity and decreased blood flow. This sequence of events has been called the "vicious cycle of erythrostasis".

Submitted for publication: February 4, 2013

Accepted for publication: May 31, 2013

Study performed at the Ophthalmology Clinic - Teaching Hospital, School of Medicine, USP - São Paulo (SP), Brazil.

Physician, School of Medicine, Universidade de São Paulo - São Paulo (SP), Brazil.

Funding: No specific financial support was available for this study.

Disclosure of potential conflicts of interest: M.T.B.C.Bonanomi, None; M.M.Lavezzo, None.

Correspondence address: Marcelo Mendes Lavezzo. Rua Raul Pompéia, 229 - Apto. 102, São Paulo (SP) - 05025-010 - Brazil - E-mail: mmlavezzo@gmail.com 
The sickle cell hemoglobinopathy with the greatest number of clinical manifestations is the SS type, which leads to hemolysis and sickling crises. Patients of the SC genotype, who present rare systemic changes, are usually those with the most severe retinal manifestations ${ }^{(5-8)}$

The frequency of retinopathy is greatest in adulthood, but retinopathy has also been described in children ${ }^{(8-10)}$. For patients bearing the SC genotype, the risk of developing proliferative sickle-cell retinopathy (PSR) is highest between the ages of 15-24 for males and 25-39 for females; for those with the SS genotype, it is higher between the ages of 25-39 for both sexes ${ }^{(8)}$.

Individuals with sickle-cell trait comprise $8 \%$ of the African-Caribbean ${ }^{(11)}$ population and over $10 \%$ of the Brazilian population ${ }^{(1)}$ Although these individuals often show no relevant clinical manifestations, they may present various retinal changes such as hemorrhages, exudates, angioid streaks, acute chorioretinal infarction, chorioretinitis, vitreous hemorrhage, retinal vascular abnormalities such as tortuous/dilated retinal veins, microaneurysms, central retinal artery occlusion and retinal proliferation ${ }^{(11-14)}$.

\section{DIAGNOSIS}

Because the early stages of sickle-cell disease often remain undetected, a meticulous eye examination is necessary. This assessment should be periodic and should include measurement of visual acuity, intraocular pressure and evaluation of the anterior/posterior segment structures by fluorescein angiography.

Ocular findings are represented by orbital, conjunctival ${ }^{(15-17)}$, uveal(18), papillary and retinal(19) alterations. The most relevant anterior segment abnormalities are the conjunctival sign and iris atrophy, both of which are diagnostic indicators of sickle-cell disease, and hyphema, for which there exists a particular therapeutic approach in these patients ${ }^{(17,20,21)}$.

In this review, we will focus on various aspects of sickle cell retinopathy and its complications.

\section{Retinal alterations}

The retinal manifestations of sickle-cell disease can be non-proliferative (yielding diagnostic value) or proliferative; in the latter case, there is a real risk of ocular morbidity. Both non-proliferative and proliferative manifestations are caused by erythrostasis secondary to sickling.

\section{Non-proliferative retinopathy}

\section{Venous tortuosity}

Vascular tortuosity is a sign described in anemia; its frequency in homozygous sickle-cell disorder reaches 50\%(22,23). However, vascular tortuosity is a nonspecific sign that is common to several diseases associated with blood hyperviscosity ${ }^{(5)}$.

\section{Hemorrhage, iridescent bodies and black sunburst}

When an arteriole of intermediate size is clogged (occluded) by a plug of sickled erythrocytes, hemorrhage may occur, presumably by ischemic necrosis of the vessel wall. This type of hemorrhage is round or oval-shaped, bright red and measures $1 / 4-1$ disc diameter. In days or weeks, a modification of the orange-red color occurs that contrasts with the dark color of the retinal pigment epithelium (RPE); the area of the hemorrhage then appears to be salmon-colored. This is known as salmon patch ${ }^{(23-25)}$. Over time, hemoglobin degradation occurs. The hemorrhagic defect then appears as bright yellow dots at several levels of the sensory retina; these are known as iridescent bodies ${ }^{(5)}$.

If the hemorrhage occurs in the outer retinal layers, it stimulates the proliferation of RPE, leading to the formation of dark, oval or round, 1/4-2 disc-diameter chorioretinal lesions. These lesions, which are similar in appearance to chorioretinitis scars, are known as black sunbursts (Figure 1) (23-25)
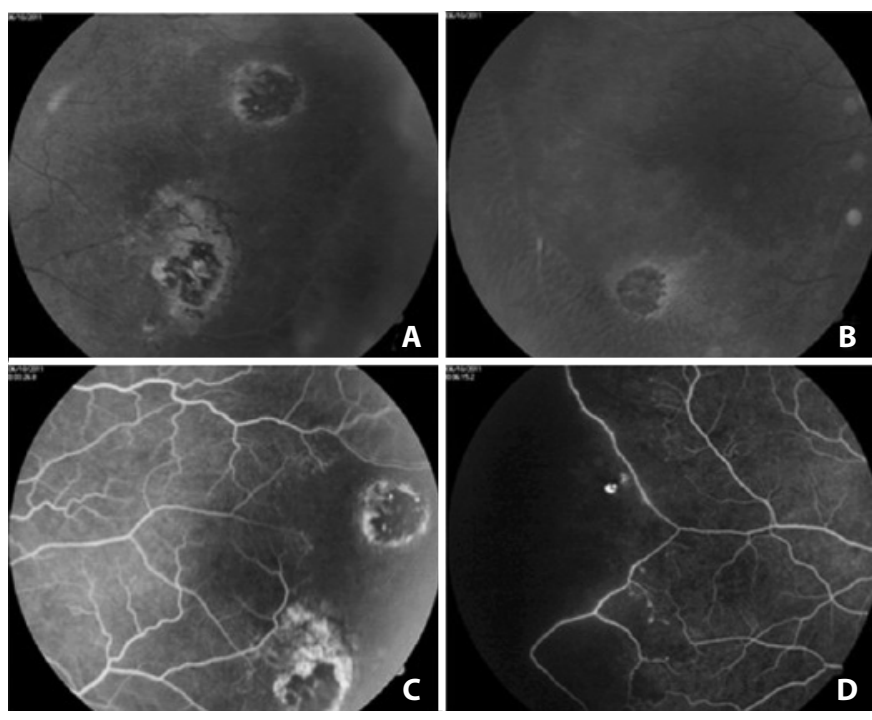

Figure 1. Patient with sickle-cell trait. A and B) Black sunbursts in the temporal and nasal peripheries of the right eye, respectively. C) Angiographic aspect of the black sunburst (window defect due to the atrophy of the RPE at the edges of the lesion and blockage by RPE mobilization to the center of the lesion). D) Temporal periphery showing the boundary between the vascularized and non-vascularized zones of the retina.

The hemorrhages are temporary, and those that occur in the posterior part of the eye are difficult to observe. Their late signs, such as iridescent bodies and black sunbursts, can be observed in approximately $25-40 \%$ of cases and are more frequent in SC hemoglobinopathy ${ }^{(5)}$.

\section{Macular changes}

Sickle-cell maculopathy occurs as a result of chronic changes in the perifoveal capillary network. It may be present in 10-40\% of patients ${ }^{(26-29)}$. The SS genotype is the most affected.

Ischemic changes are chronic and insidious, and the patient may display no symptoms. There is usually some disparity between the angiographic findings and the visual symptoms. Normal visual acuity can coexist with a very enlarged foveal avascular zone, and the presence of ischemic regions would be detected only by central visual field testing ${ }^{(30)}$. However, some patients display low visual acuity and a well-perfused macular capillary network. In these cases, an old ischemic lesion of the photoreceptors and recanalization of the affected capillaries may have occurred ${ }^{(28)}$.

In addition to the presence of an enlarged foveal avascular zone showing perifoveal capillary loss and nerve fiber layer infarcts, another finding in sickle-cell maculopathy is the formation of microaneurysm-like dots and vascular loops. These changes occur primarily in the non-perfused areas and do not cause leaking of fluorescein 26,28$)$

The incidence of acute symptoms caused by the presence of an average-sized arteriole occlusion in the macula is low. When this occurs, a thin zone of the retina, the retinal depression sign, which is linked to a scotoma or to reduced visual acuity, is formed ${ }^{(30)}$. In any case, the ischemic macular changes associated with sickle hemoglobinopathy are due to the occlusion of arteriolar circulation around the foveal avascular zone and branches that supply the temporal horizontal raphe ${ }^{(6)}$. Those changes may or may not be associated with peripheral vascular occlusion and can occur in children ${ }^{(26)}$.

Ischemic macular changes are uncommon in angiograms of patients with sickle hemoglobinopathy. With the introduction of optical coherence tomography (OCT), atrophy of the inner retinal 
layers could be demonstrated in patients with macular infarction(31); even without angiographic changes, this type of atrophy was demonstrated with spectral domain OCT (SD-OCT) ${ }^{(32)}$. These findings are consistent with the atrophy of ganglion cells, of the inner nuclear layer and of Müller cells that has been demonstrated histologically in patients suffering from chronic ischemia ${ }^{(25)}$. SD-OCT can document this atrophy even in patients with 20/20 vision (Figures 2 and 3). An initial study of patients of several genotypes showed a significantly thinner retina using SD-OCT in all macular sectors in approximately $50 \%$ of the eyes of patients of the SS (16 patients), SC (2 patients) and STahl (2 patients) genotypes compared with normal subjects of the same age group (20-60 years old $)^{(33)}$. Patients with sickle-cell disease may also have significantly reduced retinal sensitivity to microperimetry compared to those without focal thinning or to age- and visual acuity-matched controls ${ }^{(33)}$.

\section{Angioid streaks}

The incidence of angioid streaks in populations non-selected for sickle-cell is $1-2 \%{ }^{(34-39)}$.

\section{Other vascular changes}

Occlusion of the central retinal artery may rarely occur in these patients ${ }^{(40,41)}$
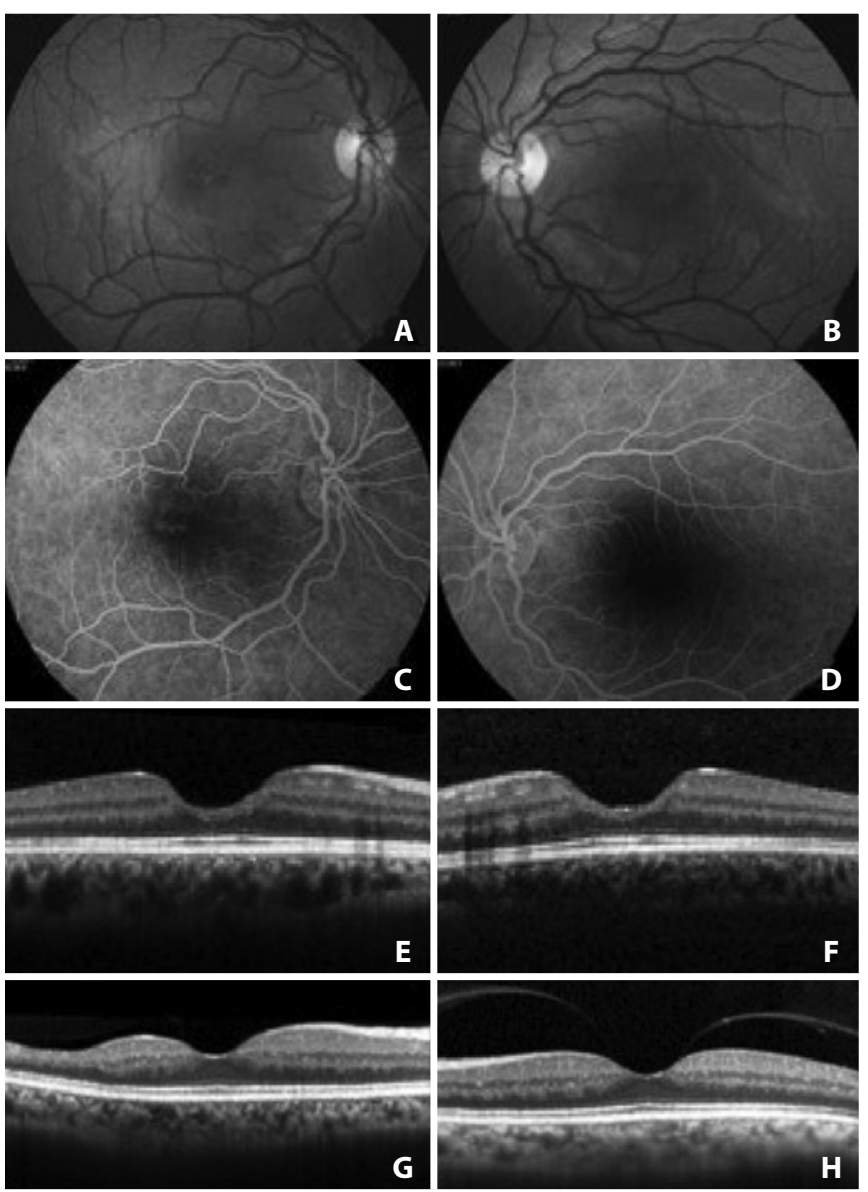

Figure 2. A 23-year-old patient with sickle cell anemia ( $\mathrm{HbA} 1-0 \%, \mathrm{HbA} 2-2.7 \%$, Fetal $\mathrm{Hb}-25.4 \%$ and $\mathrm{HbS}-71.9 \%$ ) with macular atrophy with $20 / 20$ visual acuity in both eyes. $A$ and B) Retinography. $($ and D) Fluorescein angiography. $E$ and F) Decrease of the central thickness with enlargement of the foveal depression demonstrated by spectral domain OCT. Courtesy of Dr. Aline Sokolowski da Silva. G and H) A 53-year-old patient with SS genotype with macular atrophy of the right eye (thinning of the temporal inner retinal layers) and normal macula of the left eye, demonstrated by spectral domain OCT.

\section{Optic nerve sign}

Vascular changes in the optic nerve are transient and consist of dark, small and red dilated capillaries that show occlusion in fluorescein angiography ${ }^{(22,42)}$, without any impact on acuity ${ }^{(17)}$.

\section{Proliferative retinopathy}

The involvement of vision in any stage of life of a patient with sickle-cell disease is reported to be $10-20 \%{ }^{(43)}$. Although PSR is the primary cause of visual acuity reduction in these patients ${ }^{(8)}$, the risk of this event is unknown. In a 20-year longitudinal study in which 307 SS patients and 166 SC patients were recruited at 5 years of age, it was established that the incidence of PSR is 0.5 cases/year per 100 SS patients and 2.5 cases/year per 100 SC patients ${ }^{(44)}$

The emergence and development of PSR are usually insidious, beginning in the first decade of life ${ }^{(19,45)}$. The condition remains asymptomatic until complications such as vitreous hemorrhage $(\mathrm{VH})$ or retinal detachment (RD) occur typically between $20-30$ years of age ${ }^{(46)}$. The significance of PSR as a cause of reduced visual acuity is confounded by the spontaneous regression of the neovascular complexes, which has been described in $20-60 \%$ of the cases ${ }^{(46)}$ and often occurs approximately two years after the development of proliferative lesions.

The peripheral retina, especially the temporal portion, is highly susceptible to the effects of intravascular sickling. Because it exhibits vascular network architecture of the terminal type with very thin vascular diameter, it is predisposed to occlusion. The events that lead to the occurrence of PSR typically begin in this region. Due to the insufficient number of capillaries, the collateral circulation is not developed when a vascular segment is occluded. The sequence of events was described by Goldberg ${ }^{(47)}$. The recently blocked vessel

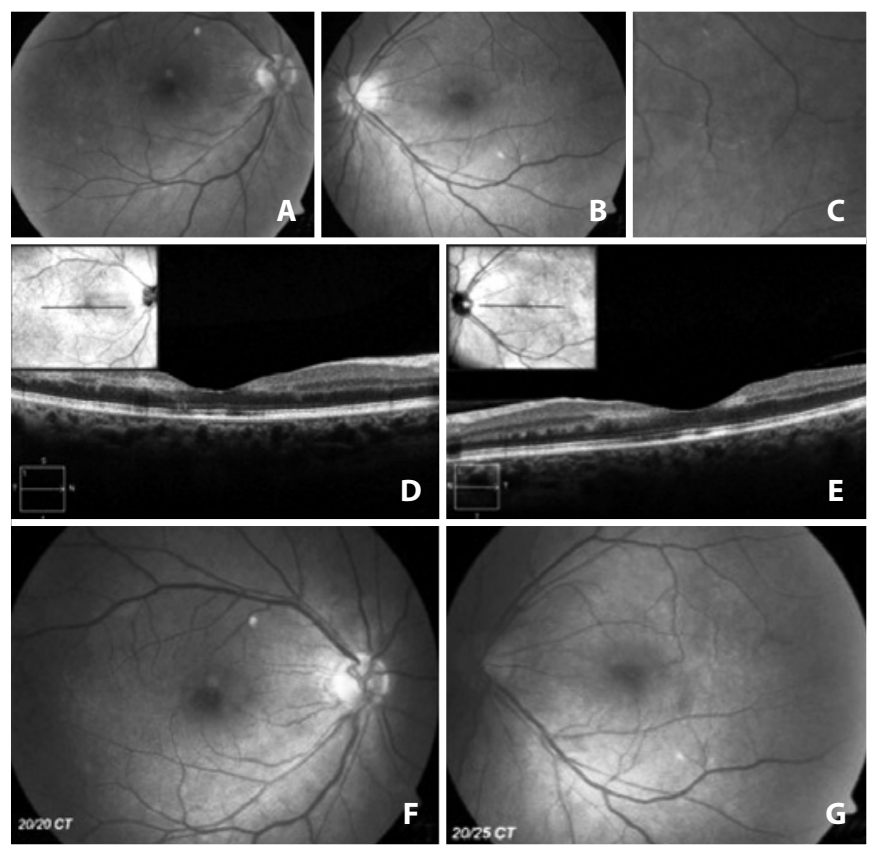

Figure 3. A 52-year-old male patient with sickle-cell trait was hospitalized for 10 days in the Intensive Care Unit due to severe pneumonia and anemia and remained on mechanical ventilation and sedation. On day 11 of hospitalization, the patient presented a sudden decrease in the visual acuity in both eyes (20/80 and 20/100). A and B) Retinography showing perifoveal retinal pallor in both eyes and sparse cotton-wool exudates. C) $\mathrm{Ar}$ teriolar branch near to the fovea showing "string of pearls" obstruction in its pathway. $D$ and $E$ ) Diffused decrease of the thickness of the inner layers of the retina, visible in the temporal region of both eyes, as demonstrated by spectral domain OCT; there is some irregularity in the RPElevel, however without compromising the outer layers of the retina. F and G) After blood transfusion, there was an improvement in visual acuity (20/20 and $20 / 25$ ) but maintenance of the structural changes in the macula of both eyes. Courtesy of Dr. Carlos Alexandre Garcia. 
can be occluded permanently and recanalized with or without the occurrence of salmon patch hemorrhage. The plugs of erythrocytes may leave the site in up to 12 hours, but remodeling of the vascular network takes months or years. If this remodeling process is efficient and forms new vascular arcades similar to normal ones, it eventually leads to the posterior formation of a peripheral capillary network (Figure 1D) without risk of sea fan development. If the remodeling is partial, an irregular vascular pattern that is more prone to neovascularization develops ${ }^{(48)}$. The irreversible vascular occlusion in the peripheral retina characterizes Stage I of the process. The occluded segment can display a "silver wire" appearance, but the ischemic phenomenon is more easily observed by fluorescein angiography (Figure 4). Following these events, there is a tortuous elongation of the arteriole end and dilation of capillaries that form arteriovenous communications in the boundary between the vascular and ischemic retinas, characterizing Stage II. The neovessels are formed from these anastomoses and are derived from the venous side of the circulation ${ }^{(49)}$. The presence of neovessels defines Stage III. Characteristically, the neovascular tuft occurs at the boundary between the non-vascularized and vascularized zones of the retinal periphery (Figures 4 and 5); the tuft is initially flat, with thin walls and located in the extreme periphery. The neovascular tuft is, therefore, difficult to diagnose ophthalmologically without a careful search, and angiography of the suspected sites can help in this process. The well-developed neovascular tissue exhibits a typical fan shape. This morphology was compared by Welch \& Goldberg ${ }^{(23)}$ to that of the marine invertebrate Gorgonia flabelum or sea fan (SF). Subsequently, a fibroglial tissue membrane develops on the SF, obscuring the blood column (Figures 4-6). At the same time, the SF tends to rise into the vitreous and form anastomoses, which leads to the emergence of large fibrous bands in the retinal periphery. The degree of perfusion of these lesions can be demonstrated by fluorescein angiography ${ }^{(25)}$

Because sickle-cell anemia is a thromboembolic disease, spontaneous regression of SF by auto-infarction may occur ${ }^{(46,50)}$ (Figure 5).
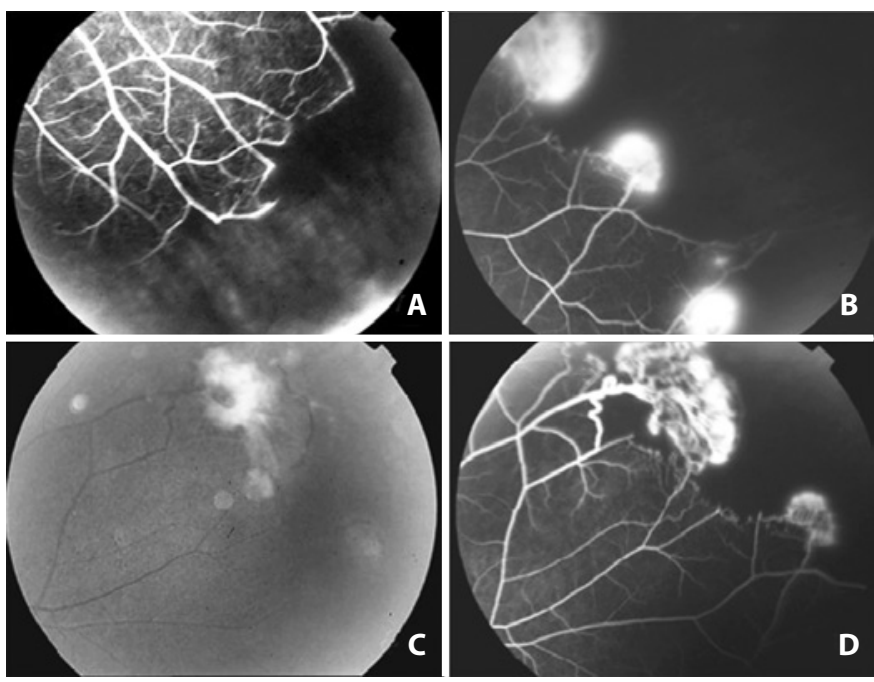

Figure 4. Proliferative sickle retinopathy at various stages in the same eye of a 47-year-old patient ( $\mathrm{HbA}-0 \%, \mathrm{HbS}-50.3 \%, \mathrm{HbC}-48.9 \%, \mathrm{HbF}-0.9 \%)$. A) Fluorescein angiography of the inferior temporal periphery showing the abrupt interruption of both the arterioles and venules of the blood column. Partial vascular remodeling has moved the peripheral vascular arcade to a more posterior position toward the equator of the eye, clearly delimiting the vascularized and non-vascularized zones of the retina (stages I and II). B) Neovessel formation or sea fan (SF) on the boundary of the perfused zone (stage III). C) Retinographical appearance of the SF, which is out of the retinal plane towards the vitreous with fibroglial proliferation on its surface and localized vitreous hemorrhage (stage IV). D) In the angiogram, this SF was intensely vascularized. In all photos of the angiogram, the wall of the retinal vessels shows no fluorescein staining; staining is only observed in the SF (a purely obstructive phenomenon). Courtesy of Dr. Gustavo Miki.
The progression is more intense in the $20-40$ year age group. The regression occurs throughout life, and it is unusual for an SF to remain perfused in patients over 40 years old who bear the SS genotype ${ }^{(46,51)}$

The term "proliferative sickle-cell retinopathy" is often used to characterize Stage III retinopathy. For patients with SS and SC hemoglobinopathies, Stage III retinopathy has a prevalence of $26 \%$ and $63 \%{ }^{(6,22)} ; 14.6 \%$, and $54.5 \%{ }^{(5)} ; 2 \%$ and $24 \%{ }^{(46)}$ and $14 \%$ and $43 \%(44)$, respectively. In addition to being more common in the SC genotype, the retinopathy is also more severe in this genotype ${ }^{(8,46)}$. The tendency to spontaneous regression occurs in both groups, and the difference between them is controversial(8,44,46). Within the SC genotype, PSR is more common when the blood levels of hemoglobin is above $12.5 \mathrm{~g}$ (73\%) compared with lower levels of $\mathrm{Hb}(15 \%)^{(6)}$.

Although most SF are small, occupying generally less than one clock hour of the retinal periphery ${ }^{(51,52)}$, they can still cause $\mathrm{VH}$. The presence of VH characterizes Stage IV. The higher the circumferential involvement of the eye by the SF, the greater the tendency for $\mathrm{VH}$ to occur $^{(52)}$ (Figure 4). The frequency of stage IV is difficult to establish because small VH near the SFs may go unnoticed; in fact, these are described in approximately $5 \%$ of cases ${ }^{(50)}$. Their occurrence is pathologically relevant because it can worsen the retinal traction, which greatly contributes to the development of RD. The abnormal traction of the SFs is often accompanied by elevation of the adjacent retina in the form of tractional retinoschisis or RD. The association between retinal atrophy (post-ischemic) and vitreous traction can lead to the
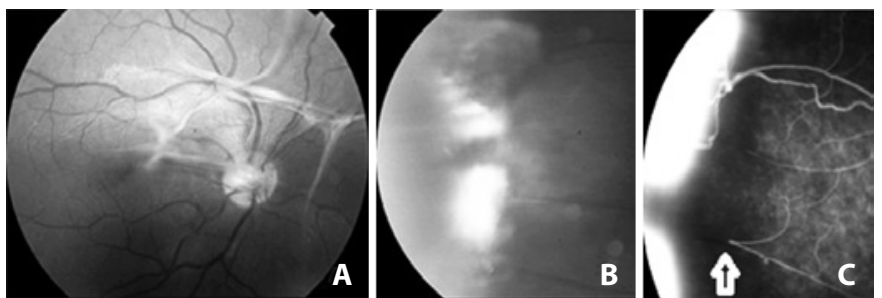

Figure 5. A) Retinography of the posterior pole of the right eye in a SC patient showing the streaks of vitreous organization. B) The temporal periphery shows three contiguous SFs with fibrous proliferation and localized vitreous hemorrhage. C) The middle SF is not perfused by the vascular loop (arrow) and suffered an auto-infarction.

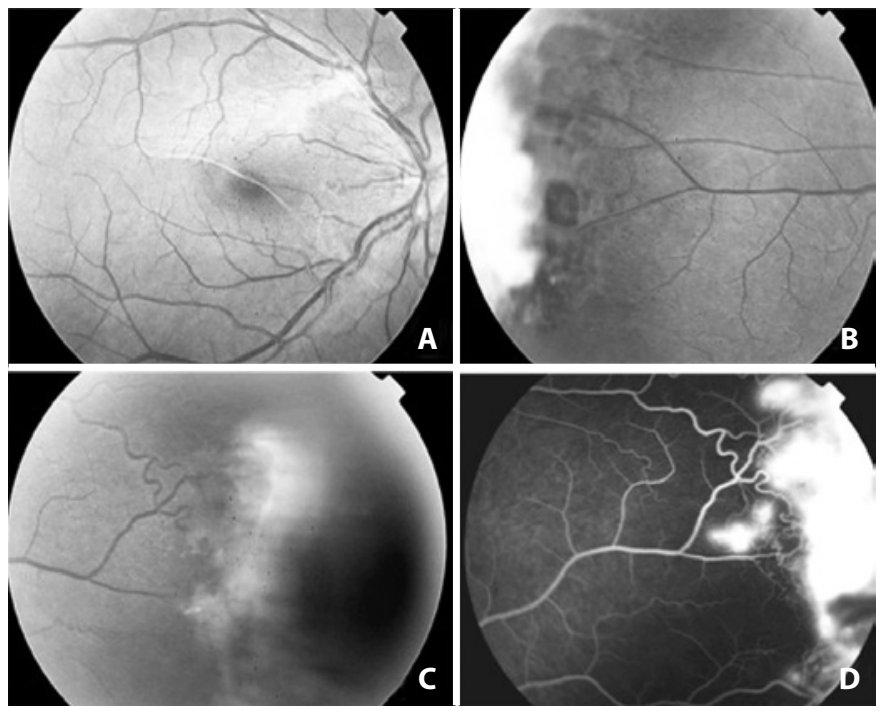

Figure 6. Complications of proliferative sickle retinopathy in a patient of SC genotype. A) Macular epiretinal membrane. B) Traction on the peripheral retina with rupture. $C$ and D) The contralateral eye of the patient, showing typical peripheral proliferative retinopathy. The tortuous vessel is the retinal arteriole that feeds the SF. 
formation of retinal tears. These are typically followed by RD, which is usually mixed and characterizes Stage V; it occurs together with VH in $1.2 \%$ of SS patients and in $13.4 \%$ of SC patients ${ }^{(5)}$ (Figure 6$)$. Blindness originating from this untreated pathological process is rare ${ }^{(44)}$; however, it has been described in $12 \%$ of cases, half of which occurred between 22-28 years of age ${ }^{(46)}$ justifying the use of preventive treatment.

The occurrence of neovascularization of the optic disc is rare $^{(22,46,49,53,54)}$.

\section{DIFFERENTIAL DIAGNOSIS}

Other diseases that occur with macular ischemia or neovascularization should be considered in the differential diagnosis of sickle-cell retinopathy. We must remember that in sickle-cell retinopathy the neovessels are always outside the vascularized retina, i.e., situated anterior to the boundary between the vascularized and non-vascularized retina; in addition, when fluorescein angiography is used, there is typically no dye in the retinal vessels in the perfused retina. This means that there is no inflammation of the vascular wall; the disease process represents a purely occlusive phenomenon (Figure 4).

The diseases that occur concomitantly with macular ischemia or neovascularization and should be considered in the differential diagnosis are ars). $^{(55)}$

I. Other causes of macular ischemia:

- Diabetic retinopathy

- Retinal vascular occlusion

- Embolic phenomena (e.g., talc retinopathy)

- Infectious diseases (dengue)(56)

II. Other causes of peripheral retinal neovascularization, VH and RD:

- Ischemic vascular disease:

a. Proliferative diabetic retinopathy

b. Branch retinal vein occlusion

c. Ocular ischemic syndrome

d. Retinopathy of prematurity

e. Eales' disease (Figure 7)

f. Familial exudative vitreoretinopathy

g. Chronic myelogenous leukemia

h. Scleral buckle

i. Hyperviscosity syndrome ${ }^{(57)}$ (Figure 8)

- Inflammatory disease with possible ischemia:

a. Sarcoidosis

b. Retinal vasculitis

c. Intermediate uveitis

d. Acute retinal necrosis

- Miscellaneous:

a. Incontinentia pigmenti

b. Autosomal dominant vitreoretinochoroidopathy

c. Old RD

\section{TREATMENT}

In sickle-cell retinopathy, VH resulting from PSR is the primary cause of reduced acuity. The treatment strategy is based on closing the $\mathrm{SF}^{(58,59)}$. Patients in stages I and II are not treated because treatment of the ischemic retina does not prevent the formation of SF, and the majority of patients do not develop SF or its complications ${ }^{(46,49,50)}$. The treatment is still controversial because many SF regress spontaneously, especially in older SS patients ${ }^{(8,50)}$, in whom the incidence of blindness is very smal|(15,36,47,60-62) . Therefore, the recommended approach is to treat SF in all SC patients and SS patients below 40 years of age with sectorial technique.

Patients with recent vitreous hemorrhage and visual acuity impairment are usually followed for at least six months to allow spontaneous clearing. Photocoagulation or cryotherapy can be performed when the visibility permits it.

\section{Sea fan treatment}

Historically, SF have been treated in a variety of ways (diathermy, cryotherapy and argon/xenon photocoagulation), always aiming to obliterate the neovessels ${ }^{(63,64)}$. Diathermy, which is no longer in use, can cause uveitis and anterior segment ischemia ${ }^{(65)}$. Cryotherapy is effective in the treatment of SF occlusion, although complications (retinal tears and tractional RD) can occur ${ }^{(66)}$. Even if the SF is not occluded, the decrease in the diameters of the neovessels renders the occurrence of $\mathrm{VH}$ less likely ${ }^{(49)}$.

Photocoagulation has been the most widely used method for treatment of PSR in Stage III retinopathy ${ }^{(60,63,64,67-74)}$. The first photocoagulation technique used was very effective in SF occlusion; this technique is known as "feeder vessel photocoagulation ${ }^{(63,68)}$. In this technique, the vessels are treated on a flat area of the retina and posterior to the SF. Initially, all feeder arterioles are treated, followed by treatment of the draining venules with less intensity. Some complications, including $\mathrm{VH}$, rupture of Bruch's membrane, choroidal hemorrhage and ischemia, retinal tears and choroidal neovascularization, can occur $(60,68,69,71,72)$.
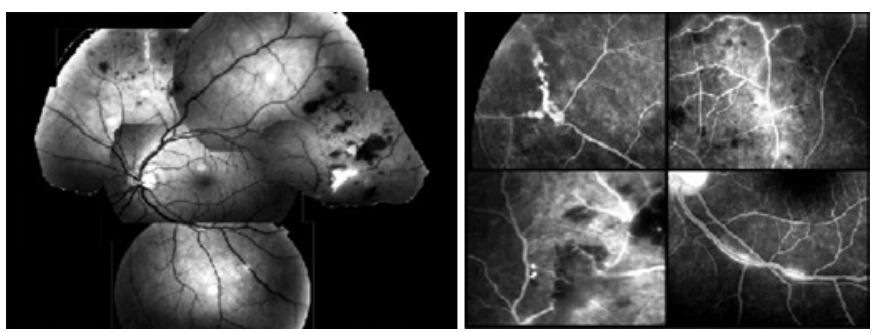

Figure 7. Differential diagnosis of sickle cell retinopathy: Eales' Disease, showing zones of hypofluorescence caused by blockage (hemorrhages). In the angiogram, note that the retinal vessel wall shows fluorescein staining that is suggestive of an inflammatory component (vasculitis). Courtesy of Dr. Polo Eduardo San Martin Gonzáles.
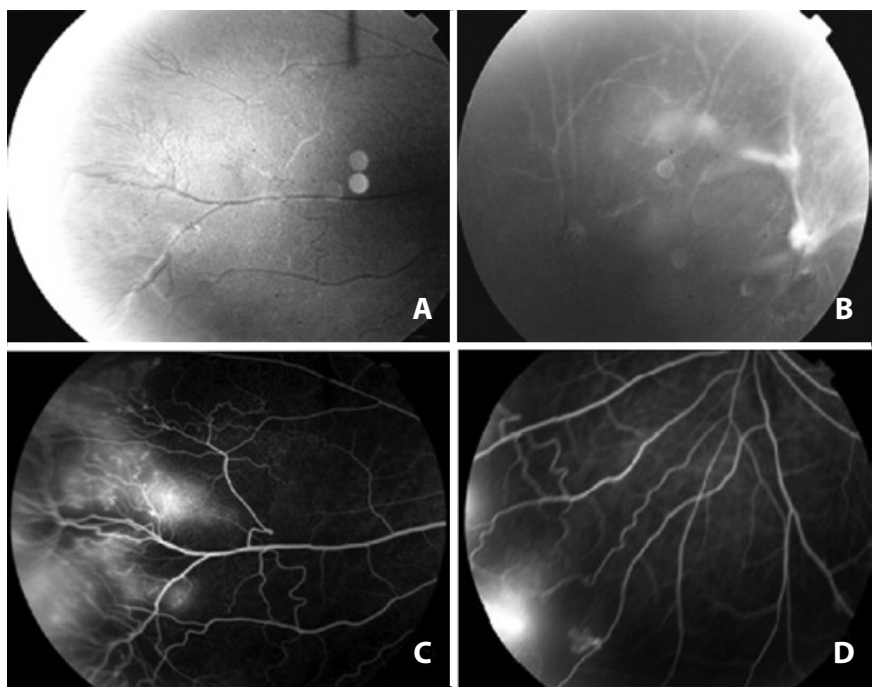

Figure 8. Differential diagnosis of sickle cell retinopathy: Hyperhomocysteinemia A) Fibroglial tissue with ghost vessels in the peripheral retina. B) Areas of RPE hyperplasia, ghost vessels and streaks of vitreoretinal fibrosis in the peripheral retina. $C$ and D) Angiogram: presence of perfused neovessels in the peripheral fibroglial proliferation. Note that the neovessels are not within the vascularized retina nor are they withed zone as in sickle cell retinopathy. Courtesy of the Arquivos Brasileiros de Oftalmologia - Misawa AK, Suzuki H, Maia Júnior OO, Bonanomi MT, Melo CS. [Obstrução arterial retiniana periférica associada com hiper-homocisteinemia: relato de caso]. Arq Bras Oftalmol. 2008;71(5):729-33. 
The photocoagulation technique currently used ${ }^{(74)}$ consists of sectorial treatment of the SF. This type of treatment has been effective and safe in the treatment of PSR in Stage III and prevents subsequent complications ${ }^{(69)}$.

\section{SURGical tREATMENT}

Surgical treatment is indicated in complications of PSR (VH and $\mathrm{RD}$ ). Because patients with sickle-cell disease are susceptible to intra- and postoperative complications, some general precautions must be taken.

The presence of VH (Stage IV) causes the first visual symptoms. Due to the high ocular morbidity that these patients exhibit during surgery, there is a 6-month waiting period for reabsorption of the $\mathrm{VH}$, after which the SF is treated with laser or cryotherapy.

The subsequent procedures must be performed with ultrasound and intraocular pressure (IOP) measurement because of the risks of concomitant RD and secondary glaucoma. Pars plana vitrectomy (PPV) is considered when the VH is massive and long in duration or if the complications listed above occur. SF treatment is performed during vitrectomy after relieving the traction on these structures. Reports of surgical treatment for $\mathrm{VH}$ are rare ${ }^{(58,75)}$. The major technical problem is the manipulation of the extreme retinal periphery, where iatrogenic breaks and cataract may occur ${ }^{(58)}$. The presence of hyphema, residual $\mathrm{VH}$ and secondary glaucoma are complications that are difficult to treat ${ }^{(17,20)}$.

The use of scleral buckle surgery to treat RD is challenging because there is a great chance that these patients will develop vascular occlusion secondary to the procedure that may progress to phthisis bulbi(59). The most effective approach is to avoid the scleral buckle technique in favor of the PPV. This can result in approximately $90 \%$ improvement of visual acuity ${ }^{(76)}$.

In a retrospective study of 27 patients, 2 of whom were SS and the remaining were SC, 10 eyes were observed with $\mathrm{VH}$ (3 patients), tractional RD (4 patients) and rhegmatogenous RD (3 patients). PPV was performed in 18 eyes of 17 patients, including VH (7 eyes), tractional RD and rhegmatogenous RD (3 eyes each), epiretinal membrane ( 3 eyes of 2 patients) and macular hole ( 2 eyes). Of the 27 patients, 15 (83\%) experienced improved visual acuity, including two patients with spontaneous resolution of RD (1 tractional and 1 rhegmatogenous). It was reported that iatrogenic breaks occurred as a result of the delamination technique used in the vitrectomy. Thus, segmentation rather than removal of traction streaks should be performed, and increased IOP should be avoided to control intraoperative bleeding and prevent intense photocoagulation. Erythrocytapheresis should be considered in SC patients ${ }^{(77)}$.

\section{General care related to surgery}

A cooperative study of sickle-cell disease in the United States reported that total mortality was $1.1 \%$ within 30 days after any surgical procedure and stated that preoperative transfusion could reduce the risk of complications ${ }^{(78,79)}$. Thus, some general preoperative precautions should be taken in addition to proper hydration, acidosis correction, and the use of saline solution and a properly heated room. The following points should be considered:

1. Blood transfusion - To reduce immediate postoperative morbidity in patients with sickle-cell disease, the Department of Apheresis of the Fundação Pró-Sangue Hemocentro de São Paulo (FPS/HSP) and the Hematology service of the Faculdade de Medicina da Universidade de São Paulo (FMUSP) have designated as standard ${ }^{\left({ }^{80}\right)}$ protocol performing erythrocytapheresis 48-72 hours prior to surgery. During the apheresis session, an exchange of the erythrocyte volume of the patient, calculated according to volemia and hematocrit, is performed. The blood replacement is isovolumetric, and concentrated erythrocytes that have been previously washed or filtered are used. The re- placement of this volume is sufficient to reduce the abnormal hemoglobin levels of the patient by 40 to $50 \%$.

2. Use of supplemental oxygen.

3. Local anesthesia should be used whenever possible to avoid hypotension with poor perfusion caused by general anesthesia.

4. Dilation of pupils - Phenylephrine drops should be avoided; parasympatholytics are preferred because they do not cause vasoconstriction in the anterior segment.

5. Decreased IOP - An IOP as low as possible should be used to improve tissue perfusion. Single doses of carbonic anhydrase inhibitors or intravenous mannitol can be used to achieve this goal. Repeated use of these drugs can cause hemoconcentration or acidosis, leading to sickling.

\section{Alternative treatments/future Perspectives}

Siqueira et al. ${ }^{\left({ }^{(1)}\right.}$ reported a case of a 36-year-old man with PSR in the temporal peripheral retina of both eyes and $\mathrm{VH}$ in the right eye. Intravitreal injection of bevacizumab $(1.5 \mathrm{mg} / 0.06 \mathrm{ml})$ was selected because the patient refused to undergo vitrectomy. There was a reduction of fluorescein leakage in the angiography one week later; four weeks later, he presented better visual acuity and regression of the neovascularization. At that time, photocoagulation of the non-perfused area of the temporal periphery of both eyes was performed. No adverse effects were described. The authors state that the results require further investigation to verify the safety of bevacizumab as well as to determine whether the neovascularization effectively regressed. This type of therapy could be useful as an adjunct to photocoagulation in the management of PSR and could obviate the need for PPV in some patients ${ }^{(81)}$. However, it is important to emphasize that for many patients there is a risk of worsening the tractional component; this risk is very common in patients with sickle-cell disease due to the use of anti-angiogenic drugs and has been well described in diabetic retinopathy.

Finally, we cannot forget that the ocular changes that compromise the vision of patients with sickle-cell disease are the consequences of a complex systemic pathophysiological process. The prevention of these ocular complications can be achieved through the use of new drugs that focus on the physiopathology of the disease. The multifaceted nature of sickle-cell disease allows the development of vascular occlusion to be arrested at multiple points, including $\mathrm{HbS}$ polymerization, erythrocyte density and cell-cell interactions. The emerging treatment options that can be employed to improve tissue perfusion in these patients include(2):

I. Increased HbF: hydroxyurea, Omega-3, erythropoietin, 2-deoxy-5-azacytidine.

II. Erythrocyte hydration: clotrimazole, magnesium pidolate.

III. Anti-adhesive/anti-inflammatory drugs: anti-adhesion antibodies, anti-integrin antibodies, anti-WF [Willebrand factor], sulfasalazine, statins.

IV. Antioxidant therapy: glutamine, deferiprone.

V. Antithrombotic agents: heparin, ticlopidine, warfarin.

VI. Vasodilation: nitric oxide, arginine, Flocor.

VII. Decrease in HbS cells: transfusion, apheresis.

VIII. Hematopoietic stem cell transplantation and gene therapy.

\section{REFERENCES}

1. Aigner CP, Sandrini F, Duarte EG, Andrade MP, Largura MA, Largura A. Estudo do perfil de hemoglobinas em 9.189 testes realizados no Álvaro Centro de Análises e Pesquisas Clínicas. Rev Bras Anal Clin. 2006;38(2):107-9.

2. Elagouz M, Jyothi S, Gupta B, Sivaprasad S. Sickle cell disease and the eye: old and new concepts. Surv Ophthalmol. 2010;55(4):359-77.

3. Araujo JT. Hemoglobinopatias anormais em São Paulo. Métodos de estudo. Incidência. J Brasil Med. 1965:9:1264-83.

4. Steinberg MH, Hebbel RP. Clinical diversity of sickle cell anemia: genetic and cellular modulation of disease severity. Am J Hematol. 1983;14(4):405-16. Review. 
5. Bonanomi MT, Cunha SL, de Araújo JT. Funduscopic alterations in SS and SC hemoglobinopathies. Study of a Brazilian population. Ophthalmologica. 1988;197(1):26-33.

6. Condon PI, Serjeant GR. Ocular findings in hemoglobin SC disease in Jamaica. Am J Ophthalmol. 1972;74(5):921-31.

7. Serjeant BE, Mason KP, Acheson RW, Maude GH, Stuart J, Serjeant GR. Blood rheology and proliferative retinopathy in homozygous sickle cell disease. $\mathrm{Br} J$ Ophthalmol. 1986;70(7):522-5.

8. Fox PD, Dunn DT, Morris JS, Serjeant GR. Risk factors for proliferative sickle retinopathy. Br J Ophthalmol. 1990;74(3):172-6.

9. Garcia CA, Fernandes MZ, Uchôa UB, Cavalcante BM, Uchôa RA. Achados fundoscópicos em crianças portadoras de anemia falciforme no estado do Rio Grande do Norte. Arq Bras Oftalmol. 2002;65(6):615-8.

10. Talbot JF, Bird AC, Maude GH, Acheson RW, Moriarty BJ, Serjeant GR. Sickle cell retinopathy in Jamaican children: further observations from a cohort study. $\mathrm{Br} J$ Ophthalmol. 1988;72(10):727-32.

11. Mehta JS, Whittaker KW, Tsaloumas MD. Latent proliferative sickle cell retinopathy in sickle cell trait. Acta Ophthalmol Scand. 2001;79(1):81-2.

12. Nagpal KC, Asdourian GK, Patrianakos D, Goldberg MF, Rabb MF, Goldbaum M, et al. Proliferative retinopathy in sickle cell trait. Report of seven cases. Arch Intern Med. 1977;137(3):325-8.

13. Jackson H, Bentley CR, Hingorani M, Atkinson P, Aclimandos WA, Thompson GM. Sickle retinopathy in patients with sickle trait. Eye (Lond). 1995;9(Pt 5):589-93.

14. Ribeiro JA, Lucena Dda R, Lucena Lda R, Jorge R. Proliferative sickle cell retinopathy associated with sickle cell trait and gestational diabetes: case report. Arq Bras Oftalmol. 2009;72(3):400-2

15. Paton D. The conjunctival sign of sickle-cell disease. Arch Ophthalmol. 1961;66:90-4.

16. Nagpal KC, Asdourian GK, Goldbaum MH, Raichand M, Goldberg MF. The conjunctival sickling sign, hemoglobin S, and irreversibly sickled erythrocytes. Arch Ophthalmol. 1977;95(5):808-11.

17. Emerson GG, Lutty GA. Effects of sickle cell disease on the eye: clinical features and treatment. Hematol Oncol Clin North Am. 2005;19(5):957-73, ix

18. Acheson RW, Ford SM, Maude GH, Lyness RW, Serjeant GR. Iris atrophy in sickle cell disease. Br J Ophthalmol. 1986;70(7):516-21.

19. Gonçalves JC, Braga JA, Nione AS, Simoceli RA, Yamamoto M. Retinopatia falciforme em crianças. Arq Bras Oftalmol. 1990;53(4):158-61.

20. Goldberg MF. The diagnosis and treatment of secondary glaucoma after hyphema in sickle cell patients. Am J Ophthalmol. 1979:87(1):43-9.

21. Goldberg MF. Sickled erythrocytes, hyphema, and secondary glaucoma: IV. The rate and percentage of sickling of erythrocytes in rabbit aqueous humor, in vitro and in vivo. Ophthalmic Surg. 1979;10(4):62-9.

22. Condon PI, Serjeant GR. Ocular findings in homozygous sickle cell anemia in Jamaica. Am J Ophthalmol. 1972;73(4):533-43.

23. Welch RB, Goldberg MF. Sickle-cell hemoglobin and its relation to fundus abnormality. Arch Ophthalmol. 1966;75(3):353-62.

24. Asdourian G, Nagpal KC, Goldbaum M, Patrianakos D, Goldberg MF, Rabb M. Evolution of the retinal black sunburst in sickling haemoglobinopathies. Br J Ophthalmol. 1975; 59(12):710-6.

25. Romayanada N, Goldberg MF, Green WR. Histopathology of sickle cell retinopathy. Trans Am Acad Ophthalmol Otolaryngol. 1973;77(5):OP642-76.

26. Asdourian GK, Nagpal KC, Busse B, Goldbaum M, Patriankos D, Rabb MF, et al. Macular and perimacular vascular remodelling sickling haemoglobinopathies. $\mathrm{Br} J$ Ophthalmol. 1976;60(6):431-53.

27. Marsh RJ, Ford SM, Rabb MF, Hayes RJ, Serjeant GR. Macular vasculature, visual acuity, and irreversibly sickled cells in homozygous sickle cell disease. Br J Ophthalmol. 1982; 66(3):155-60.

28. Stevens TS, Busse B, Lee CB, Woolf MB, Galinos SO, Goldberg MF Sickling hemoglobinopathies; macular and perimacular vascular abnormalities. Arch Ophthalmol. 1974;92(6):455-63.

29. Raichand M, Dizon RV, Nagpal KC, Goldberg MF, Rabb MF, Goldbaum MH. Macular holes associated with proliferative sickle cell retinopathy. Arch Ophthalmol. 1978; 96(9):1592-6

30. Goldbaum MH. Retinal depression sign indicating a small retinal infarct. Am J Ophthalmol. 1978;86(1):45-55.

31. Witkin AJ, Rogers AH, Ko TH, Fujimoto JG, Schuman JS, Duker JS. Optical coherence tomography demonstration of macular infarction in sickle cell retinopathy. Arch Ophthalmol. 2006;124(5):746-7.

32. Murthy RK, Grover S, Chalam KV. Temporal macular thinning on spectral-domain optical coherence tomography in proliferative sickle cell retinopathy. Arch Ophthalmol. 2011;129(2):247-9.

33. Chow CC, Genead MA, Anastasakis A, Chau FY, Fishman GA, Lim Jl. Structural and functional correlation in sickle cell retinopathy using spectral-domain optical coherence tomography and scanning laser ophthalmoscope microperimetry. Am J Ophthalmol. 2011;152(4):704-11.e2.

34. Goodman G, Von Sallmann L, Holland MG. Ocular manifestations of sickle-cell disease. AMA Arch Ophthalmol. 1957;58(5):655-82.

35. Clarkson JG, Altman RD. Angioid streaks. Surv Ophthalmol. 1982;26(5):235-46. Review.

36. Condon PI, Gray R, Serjeant GR. Ocular findings in children with sickle cell haemoglobin C disease in Jamaica. Br J Ophthalmol. 1974;58(7):644-9.
37. Condon PI, Serjeant GR. Ocular findings of elderly cases of homozygous sickle-cell disease in Jamaica. Br J Ophthalmol. 1976:60(5):361-4.

38. Hamilton AM, Pope FM, Condon PI, Slavin G, Sowter C, Ford S, et al. Angioid streaks in Jamaican patients with homozygous sickle cell disease. Br J Ophthalmol. 1981; 65(5):341-7.

39. Jampol LM, Acheson R, Eagle RC Jr, Serjeant G, O'Grady R. Calcification of Bruch's membrane in angioid streaks with homozygous sickle cell disease. Arch Ophthalmol. 1987;105(1):93-8.

40. Liem RI, Calamaras DM, Chhabra MS, Files B, Minniti CP, Thompson AA. Sudden-onset blindness in sickle cell disease due to retinal artery occlusion. Pediatr Blood Cancer. 2008;50(3):624-7.

41. Fine LC, Petrovic V, Irvine AR, Bhisitkul RB. Spontaneous central retinal artery occlusion in hemoglobin sickle cell disease. Am J Ophthalmol. 2000;129(5):680-1.

42. Goldbaum MH, Jampol LM, Goldberg MF. The disc sign in sickling hemoglobinopathies. Arch Ophthalmol. 1978;96(9):1597-600

43. Moriarty BJ, Acheson RW, Condon PI, Serjeant GR. Patterns of visual loss in untreated sickle cell retinopathy. Eye (Lond). 1988;2(Pt 3):330-5.

44. Downes SM, Hambleton IR, Chuang EL, Lois N, Serjeant GR, Bird AC. Incidence and natural history of proliferative sickle cell retinopathy: observations from a cohort study. Ophthalmology. 2005;112(11):1869-75.

45. Talbot JF, Bird AC, Serjeant GR, Hayes RJ. Sickle cell retinopathy in young children in Jamaica. Br J Ophthalmol. 1982;66(3):149-54

46. Condon $\mathrm{PI}$, Serjeant GR. Behaviour of untreated proliferative sickle retinopathy. $\mathrm{Br}$ Ophthalmol. 1980;64(6):404-11.

47. Goldberg MF. Classification and pathogenesis of proliferative sickle retinopathy. Am J Ophthalmol. 1971;71(3):649-65

48. Penman AD, Talbot JF, Chuang EL, Thomas P, Serjeant GR, Bird AC. New classification of peripheral retinal vascular changes in sickle cell disease. Br J Ophthalmol. 1994; 78(9):681-9.

49. Raichand M, Goldberg MF, Nagpal KC, Goldbaum MH, Asdourian GK. Evolution of neovascularization in sickle cell retinopathy. A prospective fluorescein angiographic study. Arch Ophthalmol. 1977;95(9):1543-52.

50. Nagpal KC, Patrianakos D, Asdourian GK, Goldberg MF, Rabb M, Jampol L. Spontaneous regression (autoinfarction) of proliferative sickle retinopathy. Am J Ophthalmol. 1975;80(5):885-92

51. Fox PD, Vessey SJ, Forshaw ML, Serjeant GR. Influence of genotype on the natura history of untreated proliferative sickle retinopathy - an angiographic study. $\mathrm{Br} J$ Ophthalmol. 1991;75(4):229-31

52. Bonanomi MT. Neovascularização da retina em hemoglobinopatia SC e hemorragia vítrea. Arq Bras Oftalmol. 1997;60(1):24-33

53. Kimmel AS, Magargal LE, Tasman WS. Proliferative sickle retinopathy and neovascularization of the disc: regression following treatment with peripheral retinal scatter laser photocoagulation. Ophthalmic Surg. 1986;17(1):20-2.

54. Ober RR, Michels RG. Optic disk neovascularization in hemoglobin SC disease. Am Ophthalmol. 1978;85(5 Pt 1):711-4.

55. Ho AC. Hemoglobinopathies. In: Yanoff M, Duker JS, editors. Ophthalmology. 3rd ed. St. Louis: Mosby Elsevier; 2009. p. 626-30.

56. Lim WK, Mathur R, Koh A, Yeoh R, Chee SP. Ocular manifestations of dengue fever Ophthalmology. 2004:111(11):2057-64.

57. Misawa AK, Suzuki H, Maia Júnior OO, Bonanomi MT, Melo CS. Obstrução arterial retiniana periférica associada com hiper-homocisteinemia: relato de caso. Arq Bras Oftalmol. 2008;71(5):729-33.

58. Jampol LM, Green JL Jr, Goldberg MF, Peyman GA. An update on vitrectomy surgery and retinal detachment repair in sickle cell disease. Arch Ophthalmol. 1982; 100(4):591-3.

59. Ryan SJ, Goldberg MF. Anterior segment ischemia following scleral buckling in sickle cell hemoglobinopathy. Am J Ophthalmol. 1971;72(1):35-50

60. Condon PI, Jampol LM, Ford SM, Serjeant GR. Choroidal neovascularisation induced by photocoagulation in sickle cell disease. $\mathrm{Br} J$ Ophthalmol. 1981:65(3):192-7.

61. Sayag D, Binaghi M, Souied EH, Querques G, Galacteros F, Coscas G, et al. Retina photocoagulation for proliferative sickle cell retinopathy: a prospective clinical trial with new sea fan classification. Eur J Ophthalmol. 2008:18(2):248-54.

62. Fox PD, Minninger K, Forshaw ML, Vessey SJ, Morris JS, Serjeant GR. Laser photocoagulation for proliferative retinopathy in sickle haemoglobin $C$ disease. Eye (Lond). 1993:7(Pt 5):703-6.

63. Goldberg MF. Treatment of proliferative sickle retinopathy. Trans Am Acad Ophthalmol Otolaryngol. 1971;75(3):532-56.

64. Goldberg MF, Acacio I. Argon laser photocoagulation of proliferative sickle retinopathy. Arch Ophthalmol. 1973;90(1):35-44

65. Condon PI, Serjeant GR. Photocoagulation and diathermy in the treatment of proliferative sickle retinopathy. Br J Ophthalmol. 1974;58(7):650-62.

66. Goldbaum MH, Fletcher RC, Jampol LM, Goldberg MF. Cryotherapy of proliferative sickle retinopathy, II: triple freeze-thaw cycle. Br J Ophthalmol. 1979;63(2): 97-101.

67. Condon PI, Serjeant GR. Photocoagulation in proliferative sickle retinopathy: results of a 5-year study. Br J Ophthalmol. 1980;64(11):832-40.

68. Condon P, Jampol LM, Farber MD, Rabb M, Serjeant G. A randomized clinical trial of 
feeder vessel photocoagulation of proliferative sickle cell retinopathy. II. Update and analysis of risk factors. Ophthalmology. 1984;91 (12):1496-8.

69. Farber MD, Jampol LM, Fox P, Moriarty BJ, Acheson RW, Rabb MF, et al. A randomized clinical trial of scatter photocoagulation of proliferative sickle cell retinopathy. Arch Ophthalmol. 1991;109(3):363-7.

70. Fox PD, Acheson RW, Serjeant GR. Outcome of iatrogenic choroidal neovascularisation in sickle cell disease. Br J Ophthalmol. 1990;74(7):417-20.

71. Goldbaum MH, Galinos SO, Apple D, Asdourian GK, Nagpal K, Jampol L, et al. Acute choroidal ischemia as a complication of photocoagulation. Arch Ophthalmol. 1976; 94(6):1025-35.

72. Jacobson MS, Gagliano DA, Cohen SB, Rabb MF, Jampol LM, Farber MD, et al. A randomized clinical trial of feeder vessel photocoagulation of sickle cell retinopathy. A long-term follow-up. Ophthalmology. 1991;98(5):581-5.

73. Jampol LM, Goldberg MF. Retinal breaks after photocoagulation of proliferative sickle cell retinopathy. Arch Ophthalmol. 1980;98(4):676-9.

74. Rednam KR, Jampol LM, Goldberg MF. Scatter retinal photocoagulation for proliferative sickle cell retinopathy. Am J Ophthalmol. 1982;93(5):594-9.
75. Ryan SJ. Role of the vitreous in the haemoglobinopathies. Trans Ophthalmol Soc $U$ K. 1975;95(3):403-6

76. Pulido JS, Flynn HW Jr, Clarkson JG, Blankenship GW. Pars plana vitrectomy in the management of complications of proliferative sickle retinopathy. Arch Ophthalmol. 1988:106(11):1553-7.

77. Williamson TH, Rajput R, Laidlaw DA, Mokete B. Vitreoretinal management of the complications of sickle cell retinopathy by observation or pars plana vitrectomy. Eye (Lond). 2009;23(6):1314-20.

78. Koshy M, Weiner SJ, Miller ST, Sleeper LA, Vichinsky E, Brown AK, et al. Surgey and anesthesia in sickle cell disease. Cooperative Study of Sickle Cell Diseases. Blood. 1985;86(10):3676-84

79. de Montalembert M. Management of sickle cell disease. BMJ. 2008;337:a1397. Review. 80. McLeod BC, Price TH, Drew MJ. Apheresis: principles and practice. Bethesda, Maryland, USA: AABBPress; 1997

81. Siqueira RC, Costa RA, Scott IU, Cintra LP, Jorge R. Intravitreal bevacizumab (Avastin) injection associated with regression of retinal neovascularization caused by sickle cell retinopathy. Acta Ophthalmol Scand. 2006;84(6):834-5



\title{
XIII Congresso Internacional de Catarata e Cirurgia Refrativa
}

\section{Congresso Internacional de Administração em Oftalmologia}

\author{
2 a 5 de abril de 2014 \\ Centro de Convenções Sulamérica \\ Rio de Janeiro (RJ)
}

Informações:

Site: www.catarata-refrativa.com.br 